\author{
Anna Kalisz \\ Maria Curie-Skłodowska University in Lublin, Poland \\ ORCID: 0000-0001-9855-0067 \\ anna.kalisz@umcs.pl
}

\title{
Right to Court in Climate Matters in the Light of the Aarhus Convention and the Case Law of Polish Administrative Courts
}

\author{
Prawo do sądu w sprawach dotyczących ochrony klimatu w świetle \\ Konwencji z Aarhus a orzecznictwo sądowoadministracyjne
}

\section{ABSTRACT}

Climate law is a fast-developing branch of law. It is regulated in a multi-centric way, since as a global issue, it needs systemic solutions that would be broader than national ones. Climate protection can also be achieved through the implementation of human rights, including the right to court. Thus, the multi-level regulation as a lex generalis is accompanied with a lex specialis regulation governing the right to court from a collective perspective and linked strictly with climate law under Article 9 of the Aarhus Convention. The theoretical and indirect aim of the article is to emphasise the relationship of environmental law in general and climate law in particular with human rights, using the example of the right to court. The direct and practical aim is to demonstrate in a horizontal manner the role of the Convention in the case law of the Polish Supreme Administrative Court. The essence of the problem is the finding of the lack of direct effect of the Convention, which weakens this protection. The article is of a scientific and research nature and the analysis of the previous case law may have cognitive value for practice. The first part provides a theoretical and legal outline of introductory issues, showing the links between human rights and climate law and the scope of application of the Aarhus Convention. The second part, concerning research materials and methods, contains an analysis of the provisions of Article 9 of the Convention made using the logical-linguistic method and teleological interpretation. The third part shows the results of the interpretation search carried out by the Supreme Administrative Court, some of them being widely accepted and some controversial. Polish administrative courts, when deciding on environmental matters under Polish administrative law, co-apply together with Polish national law the normative acts of European law, including

CORRESPONDENCE ADDRESS: Anna Kalisz, PhD, Dr. Habil., Associate Professor, Maria Curie-Skłodowska University (Lublin), Faculty of Law and Administration, Institute of Law, Plac Marii Curie-Skłodowskiej 5, 20-031 Lublin, Poland. 
the Aarhus Convention. However, the wording of its provisions precludes, according to the established case law, the possibility of their direct application, thus pointing to the importance of legislative actions, and administrative courts cannot substitute the legislature in this activity. It was noted in the conclusion that the implementation of the Convention is "generally correct", which does not mean, however, that it implements the Aarhus-type principles in full and comprehensive.

Keywords: Aarhus Convention; climate protection; environmental law; climate law; human rights; administrative courts; case law

Legal protection in environmental matters

[...] generally serves not only the individual interests of claimants, but also, or even exclusively, the public. ${ }^{1}$

\section{INTRODUCTION}

Environmental law is currently one of the most dynamically developing (and also the youngest) branches of law. Its interdisciplinary and multi-centric nature makes it a complex issue from the point of view of legal policy, including the policy of its application. The interdisciplinary character ${ }^{2}$ may be noticed in both the internal and external integration of legal sciences. ${ }^{3}$ In the internal aspect, it means encroaching on other branches of law (including especially human rights law analysed herein), while external integration manifests itself in shaping legal regulations based on non-legal sciences, mainly natural sciences, which also corresponds to postulates for the mutual use of achievements of various disciplines. ${ }^{4}$ Multi-centric character, in turn, involves the regulation of environmental issues at all levels of law: international, regional and national, and most importantly, recognising that, as a global problem, it needs wider systemic solutions than established at a national level.

The legal concept of the environment ${ }^{5}$ has a broad substantive scope,${ }^{6}$ since it comprises, i.a., renewable elements such as nature and non-renewable elements

1 Opinion of Advocate General J. Kokott in the case C-260/11, Edwards.

2 More broadly, see Klimatyczne ABC. Interdyscyplinarne podstawy współczesnej wiedzy o zmianie klimatu, eds. M. Budziszewska, A. Kardaś, Z. Bohdanowicz, Warszawa 2021, passim.

3 More on integration of legal sciences in Integracja zewnętrzna $i$ wewnętrzna nauk prawnych, eds. M. Zirk-Sadowski, B. Wojciechowski, T. Bekrycht, part 1, Łódź 2014, pp. 7-8.

4 Cf. E. Wilson, Konsiliencja. Jedność wiedzy, Poznań 2002, pp. 275-317.

5 Legal definition under Article 3 (39) of the Act of 27 April 2001 - Environmental Protection Law (consolidated text, Journal of Laws 2020, item 1219): “[... entirety of natural elements, including those transformed as a result of human activity, in particular land surface, fossils, water, air, landscape, climate and other elements of biodiversity, as well as the interactions between these elements".

6 At this point, it is worth stressing that, broadly, human life and health are also objects of regulation of the environmental law, they are not outside it, so this branch can be combined with human 
such as climate, which is also the subject of legal protection. Climate changes are a problem recognised at global, European and national levels, and the law governing this issue is characterised by a high level of dynamism, which seems to continue to grow, both in the area of the lawmaking and application of the law. ${ }^{7}$ Hence the so-called climate law (also known as climate change law) emerged - as an even younger sub-branch of environmental law, requiring effective action in terms of legal policy. It is still in statu nascendi, but the link with multi-centric protection of human rights is clearly visible. Climate protection can also be achieved through the implementation of human rights, including the right to court.

At present, the right to court (also referred to as the right to justice or the right to a fair trial) is regulated in the Polish legal system at the constitutional level (Article 45 (2) of the Constitution of the Republic of Poland ${ }^{8}$ ), the community level of the European Union (Article 47 of the Charter of Fundamental Rights, which is part of the Treaty of Lisbon ${ }^{9}$ ), the regional international level (Articles 6 and 13 $\mathrm{ECHR}^{10}$ ) and the global international level (Article $14 \mathrm{ICCPR}^{11}$ ). This approach is an example of rights and freedoms of a personal nature: the so-called first-generation human rights. Such a multi-level lex generalis regulation is supplemented by a lex specialis regulation, according to which the right to a court is regulated from a collective point of view and is strictly connected with the climate law, which is precisely what the Aarhus Convention ${ }^{12}$ of 25 June 1998 does in its Article 9. As such, it overlaps with the human right to a clean environment, i.e. it is an example of so-called collective rights (third-generation human rights).

rights. See B. Wierzbowski, B. Rakoczy, Prawo ochrony środowiska. Zagadnienia podstawowe, Warszawa 2018, p. $21 \mathrm{ff}$.

7 An example may be the so-called climate complaint, which the European Court of Human Rights publicly announced on 30 November 2020. This is a complaint in the case of Duarte Agostinho and others v. Portugal and other States (application no. 39371/20), filed by six Portuguese citizens (mostly minors) on 7 September 2020 against 33 Member States of the Council of Europe, of which 27 are also members of the European Union, including Poland. This is the first such complaint in history and is being processed as a priority.

${ }^{8}$ Constitution of the Republic of Poland of 2 April 1997 (Journal of Laws 1997, no. 78, item 483, as amended). English translation of the Constitution at: www.sejm.gov.pl/prawo/konst/angielski/ kon1.htm [access: 10.11.2021].

9 Treaty of Lisbon amending the Treaty on European Union and the Treaty establishing the European Community, signed at Lisbon on 13 December 2007 (OJ C 306/1, 17.12.2007).

${ }^{10}$ European Convention for the Protection of Human Rights and Fundamental Freedoms of 4 November 1950 (ETS no. 005, as amended).

${ }^{11}$ International Covenant on Civil and Political Rights adopted by the General Assembly of the United Nations on 19 December 1966 (United Nations, Treaty Series, vol. 999, p. 171).

${ }_{12}$ Convention on Access to Information, Public Participation in Decision-Making and Access to Justice in Environmental Matters, Aarhus, Denmark, 25 June 1998 (United Nations, Treaty Series, vol. 2161, p. 447). 
It is worth noting, therefore, that accessory rights related to climate protection are, i.a., human rights, including the right to court. This right is of particular importance among human rights (fundamental rights), as it is not just "a right in itself but also empowers individuals to enforce other rights". ${ }^{13}$

The theoretical and indirect aim of this article is to emphasise the relationship of environmental law in general and climate law in particular with human rights, using the example of the right to court, while the direct and practical aim is to show, in a cross-sectional manner, the role of the Aarhus Convention in judicial decisions of the Supreme Administrative Court (hereinafter: the SAC), which guards the rights of the individual by reviewing the legality. The essence of the problem is the finding by administrative courts of the lack of direct effectiveness of the Convention, which weakens the aforementioned protection of human rights.

The Convention itself entered into force on 30 October 2001 with regard to the countries that have ratified it. Poland ratified the agreement on 31 December 2001 (following the Act of 21 June $2001{ }^{14}$ whereby the Polish Sejm gave its consent to ratification) and it entered into force in relation to Poland on 16 May 2002.

The Convention is a rare example of a completely multi-centric protection, where many centres of making and application of law operate in the same legal space. The Parties to the Convention are currently: all the EU Member States (including the UK as a former member of the EU), the EU itself (as the legal successor of the European Community which signed and ratified ${ }^{15}$ the Convention), and third countries. At present, the signatories include 46 countries and the EU. For this reason, the Aarhus Convention is a significant act of international law, both from the point of view of environmental law (including climate law) and from the point of view of the protection of rights of the individual.

${ }^{13}$ Handbook on European law relating to access to justice, www.echr.coe.int/Documents/ Handbook_access_justice_ENG.pdf [access: 10.10.2021], p. 11.

${ }^{14}$ Act of 21 June 2001 on the ratification of the Convention on Access to information, public participation in decision-making and access to justice in environmental matters (Journal of Laws 2001, no. 89, item 970).

${ }_{15}$ Council Decision 2005/370/EC of 17 February 2005 on the conclusion, on behalf of the European Community, of the Convention on access to information, public participation in decision-making and access to justice in environmental matters (OJ L 124/1, 17.05.2005) became, therefore, part of the Community law, now the Union law. 


\section{THE RIGHT TO COURT IN CLIMATE CHANGE MATTERS IN THE LIGHT OF THE AARHUS CONVENTION - AN ANALYSIS OF LEGAL PROVISIONS}

At this point, before going into the case law of Polish administrative courts, it is worth analysing the nature and provisions of the Convention and its selected provisions using logical-linguistic and teleological interpretation of law. Both the decisions of the Aarhus Convention Compliance Committee ${ }^{16}$ and the CJEU are helpful in addressing interpretation doubts, but due to the volume of the study, they have not been subject to a separate analysis and are only referred to selectively and in an auxiliary way.

Unlike most international agreements, the Aarhus Convention (similarly in such aspect to the ECHR ${ }^{17}$ ) concerns, first of all, obligations not towards other states, but towards citizens (the so-called vertical effect), as it is a source of positive obligations of the state - but in this case not so much towards the individual as such, but towards the individual as part of society and towards society in general.

The normative content covers procedural rights, but the ratio legis, put forward in the preamble, is the intention to combine these rights with the substantive-law category of the right to live in a clean environment, of which climate is a part. ${ }^{18}$ The Convention is based on three pillars, referred to even in its very title. The first of them is access to information about the environment (regardless of citizenship or place of residence), the second - participation of citizens in decision-making processes in this area, and the third is access to justice in environmental matters, including climate matters. The study focuses precisely on the last of them, i.e. on access to appeal and judicial procedures, including in particular judicial-administrative procedures.

The third pillar of the Convention, regulated in Article 9, is in fact a "guarantee over guarantees", since the right to court (both as a lex generalis approach and as a lex specialis approach of the convention type) is not only a right in itself, but also enables individuals to enforce other rights. Access to justice is a basic element of

16 The Compliance Committee is a special committee established by a decision taken at the first meeting of the Parties, namely the Conference of the States Parties to the Aarhus Convention in 2002, which is now composed of nine independent experts appointed by the Conference of the parties for a 6-year term of office. The Committee's role is to advise the meeting of the parties by, i.a., issuing opinions on compliance with the Convention.

${ }^{17}$ But taking into account essential differences between these agreements, especially the adjudicating body established for the ECHR.

18 " $[. .$.$] every person has the right to live in an environment adequate to his or her health and$ well-being, and the duty, both individually and in association with others, to protect and improve the environment for the benefit of present and future generations [...] to be able to assert this right and observe this duty, citizens must have access to information, be entitled to participate in decision-making and have access to justice in environmental matters". 
the right to court, but itself is a several-element set of rights that partly reinforces the previous two pillars and partly constitutes an independent right. ${ }^{19}$

The access to justice referred to in Article 9 of the Convention includes in its scope the proceedings arising out of infringement of rights under pillar I and pillar II, i.e. the right to information and the right to participate in decision-making in environmental matters. ${ }^{20}$ Thus, in the case of paras. 1 and 2 , it is primarily complementary in nature.

Pursuant to para. 1, "any person who considers that his or her request for information under article 4 has been ignored, wrongfully refused, whether in part or in full, inadequately answered, or otherwise not dealt with in accordance with the provisions of that article, has access to a review procedure before a court of law or another independent and impartial body established by law. In the circumstances where a Party provides for such a review by a court of law, it shall ensure that such a person also has access to an expeditious procedure established by law that is free of charge or inexpensive for reconsideration". This means that any natural or legal person who applies for this is entitled (even without proving any interest in the case $^{21}$ ) to obtain the requested information, and any refusal to provide it (the reasons for which are to be interpreted narrowly) is subject to appeal. The complementarity of such provision consists in the fact that it secures pillar I - the universal right of access to environmental/climate information.

But para. 2 of Article 9, concerning to pillar II, i.e. the participation of society in the decision-making process in environmental matters, is not of a universal nature. This is because it reduces the circle of entitled bodies to "members of the public concerned" who, in addition, have a "sufficient interest" 22 or maintain that a right has been impaired, if the provisions of the administrative procedure of a particular signatory state require it as a prerequisite. The right, on the other hand, is the "access to a review procedure before a court of law and/or another independent and impartial body established by law, to challenge the substantive and procedural legality of any decision, act or omission subject to the provisions of Article 6" concerning public participation in decision making. This provision, unlike para. 1, raises interpretation doubts, both in the subjective and objective terms, as regards the freedom of

19 I. Przybojewska, Trzeci filar konwencji z Aarhus oraz rola Komitetu ds. Przestrzegania Konwencji z Aarhus, "Europejski Przegląd Sądowy" 2020, no. 10, p. 23.

${ }^{20}$ Cf. M. Kenig-Witkowska, Prawo ochrony środowiska Unii Europejskiej. Zagadnienia systemowe, Warszawa 2011, p. 30; A. Knade-Plaskacz, Dostęp do wymiaru sprawiedliwości w sprawach dotyczacych środowiska - transpozycja trzeciego filaru Konwencji z Aarhus do prawa Unii Europejskiej, "Przegląd Prawa Ochrony Środowiska" 2014, no. 1, p. 222.

${ }^{21}$ See B. Filipcova, Polskie przepisy dotyczace dostępu do wymiaru sprawiedliwości w sprawach środowiskowych - analiza istniejacych barier, "Europejski Przegląd Sądowy" 2020, no. 11, p. 36.

${ }^{22}$ It is worth noting the concept of "interest" for administrative law. More broadly, see A. Duda, Interes prawny w polskim prawie administracyjnym, Warszawa 2008, passim. 
assessment, or even the "margin of appreciation", of the signatory states as to the specification of the requirements that should be met by non-governmental organizations (since the provision mostly applies to them). The definition of "the public concerned" is set out in Article 2 (5) of the Convention, and the determination of sufficient interest and impairment of a right is to be carried out in accordance with the requirements of national law, but this freedom may not, however, lead to a real limitation of rights under the Convention. According to the standards of the Compliance Committee, the precondition of "sufficient interest" may not be subject to interpretatio restrictiva, as this would hinder the implementation of the Convention's objectives. ${ }^{23}$ The objective scope of the right under para. 2 should also be understood broadly, without restricting the categories of decisions only to those that relate strictly to the natural environment, which is supported by both the Committee ${ }^{24}$ and the CJEU. ${ }^{25}$ Therefore, it is not so much about the environmental protection law, but all the law that is related, also indirectly, to environmental protection. In this area, members of the public concerned may question decisions as to an action or inaction for both substantive and formal reasons.

On the other hand, para. 3 of Article 9 states that "where they meet the criteria, if any, laid down in its national law, members of the public have access to administrative or judicial procedures to challenge acts and omissions by private persons and public authorities which contravene provisions of its national law relating to the environment". This provision thus "detaches" itself from the other pillars of the Convention and creates an independent right which can be viewed as an individual procedural right. This provision gives the right to bring a legal action (locus standi) to challenge any act or omission in a court of law (including those unrelated to pillar I or pillar II) of both public authorities and private parties, based on substantive or formal grounds. Therefore, it has both vertical and horizontal effect, which corresponds to the nature of the right to court in its "classical" conceptualization as the said lex generalis. An important reservation here, however, is the fulfilment of national law requirements, which may raise interpretative questions. As for the case of para. 2, when drafting national law and formulating these criteria, the aim of the Convention must be kept in mind, i.e. the broad access to justice and effective enforcement of rights. It is beyond doubt that the State's obligations under para. 3

${ }^{23}$ The Committee's position is in line with the judgement of the SAC of 3 March 2016, II OSK $1674 / 14$.

${ }^{24}$ I. Przybojewska, op. cit., pp. 23-24.

25 Judgement of the CJEU of 12 May 2011, C-115/09, Bund für Umwelt und Naturschutz, ECLI:EU:C:2011:289. The Court has also specified admissible criteria that may be established by Member States in national legislation for environmental NGOs. See judgement of the CJEU of 15 October 2009, C-263/08, Djurgården-Lilla, ECLI:EU:C:2009:631. 
of the Convention relate to both administrative and judicial procedures. ${ }^{26}$ Para. 3 of Article 9 is devoid of direct effect and in order to provide its implementation, it requires another normative act to be adopted at the national level to set out all the requirements for the exercise of the rights listed in this provision. ${ }^{27}$ Paras. 4 and 5 of Article 9 of the Convention set out the standards for the procedures referred to in paras. 1 to 3 .

Therefore, access to justice in environmental matters is differentiated by Article 9 of the Convention itself, which regulates the elements of the right to court differently in issues relating to access to information, decision-making processes and other matters.

The provisions of Article 9 of the Convention, as provisions of a ratified international agreement entail, at the level of application of the law, the obligation to apply ex lege. The obligation covers also an interpretation conforming to the Community law and, if necessary, to apply the principle of precedence (primacy), and at the level of law-making the obligation to remove all the contradictions that may result in conflicts of laws.

\section{THE AARHUS CONVENTION - APPLICATION BY ADMINISTRATIVE COURTS}

The Aarhus Convention is both an international agreement (originally adopted as a UN convention) to which the Republic of Poland is a party, and a part of the EU law (with additionally adopted secondary legislation to implement it). Due to its position in the system of sources of generally binding law (which is further empowered by its dual status), the Convention is applied by Polish courts, including administrative courts. ${ }^{28}$ Therefore, they are to operationalise the Convention at individual level, which corresponds to the Committee's stand-

${ }^{26}$ See Annex to Decision no. 2005/370 containing EC declaration made pursuant to Article 19 (5) of the Convention, as regards determination of the scope of powers related to matters governed by the Convention.

${ }^{27}$ See judgement of the CJEU of 8 March 2011, C-240/09, Lesoochranárske zoskupenie VLK, ECLI:EU:C:2011:125. An extensive analysis of this issue is contained in: B. Iwańska, M. Baran, Access of An Environmental Organisation to Court in Light of the EU Standard Set by the Principle of Effective Legal (Judicial) Protection, "European Energy and Environmental Law Review" 2019, vol. 28(2), p. $47 \mathrm{ff}$.

28 See judgement of the SAC of 16 March 2010 (II OSK 540/09), stating that "as regards access to justice for environmental organizations representing the public, the court of first instance was also obligated, apart from the provisions of Directive 85/337/EC, to take into account the provisions of Article 9 of the Aarhus Convention, which, as an international agreement, may be applied directly". The context suggests, however, that the case concerned interpretation in the light of the Convention, not its direct, independent application. 
ard, pursuant to which the bodies reviewing environmental decisions should be empowered to review legality in both substantive and formal terms. ${ }^{29}$ However, respective case law in question can change depending on the legislative actions and policy of the Committee, and - above all - the Court of Justice.

According to the general model of legality review, administrative courts carry out the review in reference to national law, international agreements and EU law. In this respect (including the Aarhus Convention), they are required to interpret the national law in accordance with the Convention and to apply the principle of primacy in case of conflict with national provisions. Most often cases, where the Aarhus Convention is part of the validation and interpretation findings, are heard by the General Administrative Chamber of the SAC (but sometimes they are heard also by the Commercial Chamber). The following review of the case law covers the entire period of application of the Convention in Poland.

The first administrative-judicial decisions invoking the Convention focused first and foremost on the question of legal aid, in the field of exemption from the payment of court fees. A number of court orders issued in the first decade of the Convention's implementation were based on the thesis of the SAC of 2 June 2005 (II OZ 503/05), which stated that "the Aarhus Convention [...] did not provide for a requirement of exemption from court fees, but only a requirement to consider establishing an appropriate aid mechanism to remove or reduce financial and other restrictions on access to justice". Therefore, this does not entail an obligation for the State to fully exempt NGOs from court fees in matters governed by the Convention (and the norms of the Law on proceedings before administrative courts additionally provide for the possibility to apply individually for legal aid under general conditions). Thus, as regards the costs of the proceedings, Article 9 of the Convention refers to the provisions of national law that are not inconsistent with the Convention.

As this line of case law established over time, the emphasis was shifted, around year 2010, from the issue of automatic exemption from costs to the very access to court and participation in the proceedings. However, the Convention also refers to national legislation in the field of the assessment of the party's locus standi (right to bring a legal action). ${ }^{30}$ In its judgement of 18 December 2009 (II OSK 1539/09), the SAC stressed that "the Convention guarantees access to the procedure before

${ }^{29}$ Cf. communication of the Compliance Committee of 24 September 2010 concerning the United Kingdom, ACCC/C/2008/33/UK.

${ }^{30}$ As regards this point, see decision of the SAC of 2 February 2010, II OSK 40/10 (a similar position was previously presented in the following cases, in which the SAC rejected allegations of violation of the Convention by refusing the participation of NGOs in administrative court proceedings: OSK 1151/04, II OZ 1146/05, II OSK 129/06, II OSK 163/07, II OSK 763/07, II OSK 1393/07, II OSK 464/09). 
the courts to members of the public concerned, but refers to the regulations contained in national laws as regards the assessment of the party's capacity to sue and be sued". The provisions of the Convention do not therefore extend the personal scope of the entitled with regard to Polish law. ${ }^{31}$

It is worth noting that these cases are examined ad casum, e.g., in the judgement of 16 March 2010 (II OSK 540/09) concerning the case of a challenged refusal to initiate proceedings due to lack of a locus standi, the SAC revoked the judgement under appeal and referred the case back for reconsideration. The arguments were based, i.a., on Article 9 of the Convention (applied along with national law). The essence of the dispute boiled down to assessing whether the demand of the association was supported by the public interest or not, hence the SAC considered it justified to jointly examine if all the objections formulated in the cassation appeal are justified. It also instructed the court of first instance that the provisions of the Aarhus Convention, although of general wording, should be taken into account when looking for a general public interest. ${ }^{32}$ Nevertheless, in such case, the argument based on the Convention was of an ornamental nature. In the SAC's opinion, the provisions of Polish law ensuring the protection of environmental NGOs are adequate and at the same time consistent with constitutional and international law, so the arguments ad Aarhus constitute an additional reason.

As mentioned above, the judicial capabilities of administrative courts are related to legislative action at the national level. The Act of 9 October 2015, ${ }^{33}$ which is the main instrument of implementation pillar I and pillar II of the Convention, amended, added or repealed the provisions of the Act of 3 October 2008 on the dissemination of information on the environment and its protection, public participation in environmental protection and on environmental impact assess-

${ }^{31}$ Similarly, judgement of the SAC of 19 November 2014, II OSK 1071/13. As regards the latest case law, in case II OSK 1479/17, the SAC stressed that "the provisions of the Aarhus Convention state that an environmental organization must comply with the requirements of national law. Thus, national law may impose on an organization requirements that must be met by the organization to have the right to participate in the proceedings. In the opinion of the SAC, Polish legislation implements the directives stemming from this act", while in the case no. II GSK 985/15, the Court noted that "the admissibility of judicial proceedings in the present case cannot be derived from the provisions of the Aarhus Convention referred to in the cassation appeal, since these are provisions addressed to the parties to the Convention, which require the parties (the states and the European Community) to take certain measures to achieve the objectives of the Convention".

32 Similar arguments are presented in: judgement of the SAC of 31 August 2012, II OSK 851/11; judgement of the SAC of 16 January 2013, II OSK 1706/11; judgement of the SAC of 3 December 2019, II OSK 3303/19.

33 Act of 9 October 2015 amending the Act on the prov II OSK 833/16 ision of information on the environment and its protection, public participation in environmental protection and on environmental impact assessments and on certain other acts (Journal of Laws 2015, item 1936). The provision of Article 9 (3) has been implemented with provisions governing individual procedures. 
ments, ${ }^{34}$ and the purpose of the amendment was to implement the provisions of the Convention to the Polish legal system more comprehensively. The amendment extended the list of entities obliged to provide information on the environment and its protection by introducing a definition of "public authorities", which, apart from administrative bodies, also included bodies performing legislative and judicial functions. The SAC in its case law positively assessed these changes. ${ }^{35}$

The most controversial (from the point of view of the parties to the proceedings and entities authorised under Article 9 of the Convention) position presented in the case law of administrative courts is the recognition of the lack of the attribute of direct application (self-executing character) of Article 9 of the Aarhus Convention, which the SAC pointed out on many occasions. The ruling in case II GSK 1307/12 states that these are "provisions addressed to the parties to the Convention, which require these parties (the states as well as the European Community) to take certain measures to achieve the objectives of the Convention". In judgement of 1 October 2015 (II OSK 896/15), the SAC noted that "the provisions of this Convention set the general directions of change in the legislation of the states that ratified it", and it was also previously argued that "these are norms formulated in very general terms, which need to be made more specific in the domestic legal systems of the Aarhus Convention signatory states. This is evident from the provisions of Article 9(1) to (5) of this international agreement, which provided for the introduction into the legal systems of the member states the specific review procedures enabling a case to be heard by a court or other independent and impartial body established by law" 36 and that "it should be emphasized that $[\ldots]$ the Aarhus Convention [...] is not an international agreement that can be applied directly without requiring changes to the legal system of the State that has signed and ratified this Convention. Referring to and analysing the content of [...] Article 9 of the Convention, it should be pointed out that the above-mentioned provisions show that the provisions of the Aarhus Convention cannot be applied directly. They are an obligation imposed on the authorities of the State which has ratified that Convention to take legislative action and to enact statutes which will give effect to the provisions of that Convention". ${ }^{37}$ Thus, Article 9 of the Convention

34 Journal of Laws 2013, item 1235, as amended.

${ }^{35}$ See judgement of the SAC of 9 June 2016, II OSK 2415/14; judgement of the SAC of 19 January 2018, II OSK 1721/16, referring to the former, in which the SAC stated that "it is beyond dispute [...], that Article 9 (1) to (5) of the Aarhus Convention and the [...] directives [...] have been implemented into the Polish legal system [...]. In the assessment of the SAC, the Polish legislation implements directives stemming from these acts of international law and EU law". Similarly judgement of the SAC of 19 January 2018, II OSK 833/16.

36 Judgements of the SAC in cases: II OSK 1274/12, II OSK 1282/12, II OSK 2489/12, II OSK 2808/13, II OSK 1920/14, II OSK 2244/14.

37 Judgement of the SAC of 15 April 2010, II CK 645/09, II OSK 645/09. See also judgement of the SAC of 23 February 2011 (II OSK 2516/10) referring to this judgement, and the judgements in cases: II OSK 2103/10, II OSK 2022/10 and II OSK 548/11. Similarly, also judgement of the 
"does not meet the criterion of direct application referred to in Article 91 (1) of the Constitution, since a law must be enacted to allow the Convention to be applied". ${ }^{38}$

The case law of the SAC stresses that "Poland has undertaken appropriate actions and has introduced into the internal legal order the standards allowing public participation in decision-making and access to information in environmental matters" 39 and thus - as pointed out in the latest Convention-referring judgement of 18 May 2020 (II OSK 2710/19), by which the SAC dismissed cassation appeals (including one filed by the Commissioner for Human Rights) in a case of which the appellate administrative body had refused the applicant's status as a party and terminated the proceedings - "the provisions of international law and the EU law were correctly implemented on the grounds of Polish law, therefore the objection [...] and the absence of any consideration in the substantiation of the judgement under appeal about the applicability of Article 9 (3) of the Aarhus Convention should be considered unfounded".

However, the lack of direct effect neither means that the provisions of the Convention are not normative in nature, nor that the Convention is to be ignored in decision-making processes in cases pending in administrative courts.

At the same time, the SAC stresses the role of the Convention in the application of Polish law by interpreting this law in a manner conforming to the Convention ("the pro-Aarhus interpretation"). According to the line of case law presented in cases II OSK 1131/14 and II OSK 2189/14, "the general nature of the regulation contained in Article 9 of the Aarhus Convention makes this provision devoid of direct effect $[\ldots]$. On the other hand, it is the national court's responsibility to interpret, as far as possible, the procedural provisions concerning the conditions which must be met to initiate administrative or judicial proceedings in accordance with the objectives of Article 9 (3) of the Convention and with the aim of effective judicial protection of rights". The SAC stressed in the reasoning of the judgement

SAC of 6 December 2013 (II OSK 54/12) and subsequent judgements in cases II OSK 2970/15 and II OSK 2192/16 ("According to Article 91 (1) of the Constitution of the Republic of Poland, after promulgation in the Journal of Laws of the Republic of Poland, a ratified international agreement shall constitute part of the domestic legal order and shall be applied directly, unless its application depends on the enactment of a statute. The Aarhus Convention [...] is not an international agreement that can be applied directly without requiring changes to the legal system of the State that has signed and ratified this Convention. This is evidenced by the wording of the provisions of the Convention. [...] They are an obligation for the authorities of the State which has ratified this Convention to take legislative action and establish provisions that will implement the provisions of this Convention. [...] The obligations set out in the Convention have been duly implemented in the national legal system").

${ }^{38}$ For more detail, see judgement of the SAC of 24 April 2018 (II OSK 2743/17), very broadly discussing this issue and with the development of arguments on the lack of direct application of Article 9 of the Convention.

39 See judgement of the SAC of 1 June 2010, II OSK 920/09; judgement of the SAC of 28 July 2016, II OSK 1076/15 referring thereto. 
of 3 March 2016 (II OSK 1674/14): "[...] the Convention is a ratified international agreement which is an act having precedence over a statute" and the provisions of Polish law "cannot therefore be interpreted in isolation from this Convention". ${ }^{40}$

In the case II OSK $2415 / 14$, the SAC stressed that "the wording of the provisions of both the Aarhus Convention and the cited Directive [no. 2011/92/EU] excludes the possibility of their direct application. On the other hand, where these provisions have been implemented into the Polish legal order, their interpretation cannot lead to conclusions that would manifestly contradict clearly formulated provisions of the implementing statute". ${ }^{41}$ Nevertheless, "this Convention, as an international agreement binding on Poland, has become, pursuant to Article 91 (1) of the Constitution [...] a part of the national legal order and must be applied within the Polish legal order". ${ }^{42}$ By judgement of 8 May 2019 (II OSK 652/19) the SAC upheld the cassation appeal on the grounds that "the charges of infringement of the provisions of national law by failing to interpret them in accordance with the provisions of the Aarhus Convention, as well as the legal consequences in the sphere of national law, as argued by the applicant, contain [...] justified grounds".

To sum up, Polish administrative courts, when deciding on environmental matters under Polish administrative law, co-apply together with Polish national law the normative acts of European law, including the Aarhus Convention. In such cases, the legality review is of a multi-centric nature. The Convention, therefore, forms part of the national legal order (both as an international agreement and as part of the EU law) and is directly applicable, but in practice the wording of the Convention precludes its direct effect, thus increasing the significance of national acts and regulations. ${ }^{43}$ On the other hand, the national courts are required to "perform, i.a., the function of a pro-EU interpretation of law" and, as part of this capacity, to conduct a "pro-Aarhus" interpretation, and the application of the Convention should consist in such coherent interpretation.

It is also noted in the case law that Article 9 itself, in para. 1, provides that each of the parties which ratified the Convention shall ensure that its provisions are implemented "within the framework of its national legislation", and that therefore administrative courts, which have powers to rule within their jurisdiction, cannot replace legislative action in this respect.

40 The obligation of interpretation of national law "in the light of the Aarhus Convention and EU law" results also indirectly from judgements of the SAC of 12 May 2015, II OSK 2036/13, and of 16 July 2015, II OSK 1044/15.

${ }^{41}$ Similarly in the cases II OSK 2859/16 and II OSK 2335/17.

42 Judgement of the SAC of 12 December 2017, II OSK 1523/16.

43 Judgement of the SAC of 21 April 2011, II OSK 2022/10; judgement of the SAC of 15 November 2019, II OSK 3276/17. 


\section{CONCLUSIONS}

Access to justice in matters covered by the Aarhus Convention is, on the one hand, of a subsidiary nature (it supports the right of access to information and the right to participate in decision-making) and, on the other hand, of an autonomous nature as the right to challenge acts or omissions of public authorities or private entities affecting the environment. In this area, "international, EU and national legal systems have been brought together under a set of common values". ${ }^{44}$ Therefore, on the one hand, it is possible to talk about indistinguishable protection standards, but on the other hand, it should be kept in mind that these standards are just in the process of being formed both at the EU and national levels.

The norms resulting from the provisions of the Convention are reflected in national provisions, primarily environmental law ensuring public participation in environmental matters, but also in other laws, as the Convention has been implemented generally correctly, and its provisions correspond to those of the generally binding law in the Republic of Poland. However, a "generally correct" implementation does not in this case mean an implementation that fully embodies the Aarhus-type principles.

The Convention itself does not contain specific provisions on the effects of Article 9 (3) in the legal systems of the signatory States and in the law of the EU and its member states. ${ }^{45}$ Moreover, the situation is even more complicated by the fact that environmental protection is a shared competence of the EU but, according to the doctrine of "occupied field", not covered by EU regulations yet.

In view of the absence of legislative action at the Union level to clarify the provision of Article 9 (3) of the Convention (although, as mentioned before, the EU has already adopted legislation to achieve the objectives of the Convention) the operationalisation of the powers under the Aarhus Convention (as well as under EU law in general) takes place within the framework of the institutional and procedural autonomy of the member states. ${ }^{46}$ This means that access to court in environmental matters is carried out within the framework of the requirements of national procedures and the protection of the right is (and depends on) the responsibility of the courts of the Member States, including the administrative courts. The EU case-law also emphasizes that "the obligations [...], which derive from Article 9 (3) of the Aarhus Convention with respect to national administrative or judicial procedures,

${ }^{44}$ B. Iwańska, Zróżnicowanie i ograniczenia $w$ dostępie do wymiaru sprawiedliwości w sprawach ochrony środowiska. Uwagi na tle implementacji konwencji z Aarhus w prawie unijnym, "Europejski Przegląd Sądowy" 2020, no. 10, p. 7.

${ }_{45}$ A. Knade-Plaskacz, op. cit., p. 227.

${ }^{46}$ M. Baran, Dostęp do wymiaru sprawiedliwości w obszarze ochrony środowiska w państwach członkowskich, "Europejski Przegląd Sądowy" 2020, no. 11, p. 16. 
which, as EU law now stands, fall primarily within the scope of Member State law" ${ }^{47}$ which will remain so unless and until the Community, "in the exercise of its powers under the EC Treaty, adopts provisions of Community law covering the implementation of those obligations". ${ }^{48}$

The provision is not directly applicable: its wording is too general, as noted both by national courts and practitioners as well as scholars of EU law. ${ }^{49}$ Therefore, its application depends on the legislation and, consequently, on the content of the national law. Also the SAC stresses in its rulings that the provisions of the Aarhus Convention do not have a normative character: "The Aarhus Convention [...], which binds the Republic of Poland, is not an international agreement that may be applied directly without changes in the legal system of the state which has signed and ratified it". ${ }^{50}$ It is, therefore, necessary to adopt relevant regulations in this field.

Thus, although the Polish (as well as EU's) legal acts adopted to implement the Convention are not, in principle, inconsistent with the Convention, neither the Union nor the Polish state have fully implemented the provisions of the Convention in terms of access to justice in environmental matters. It is worth pointing out that the activity of the CJEU, although undoubtedly significant in respect of unification of standards, is nonetheless insufficient and will not replace the legislation either at the EU or at the national levels. ${ }^{51}$

For the EU legal system, the Aarhus Convention means the necessity to act within the framework of shared competence of EU bodies, and for the signatory states and the EU, to apply the norms of the Convention and the so-called Aarhus-type principles in their legislation and in applying law and considering cases by administrative bodies and courts, including primarily administrative courts. The fact that the Union, as a legal entity and successor to the EC, is a party to the Convention makes it possible to subject its provisions to interpretation under Article 267 of the Treaty on the Functioning of the European Union, which to some extent compensates for the lack of direct effect adopted by administrative courts and may make the "pro-Aarhus" interpretation easier.

Nevertheless, the provisions of the Convention are, to a large extent, an obligation for the state authorities to take specific legislative actions and to adopt provisions implementing it more comprehensively. These actions must be taken by the Polish state not solely as a signatory to the Convention and an EU Member

47 Judgement in joined cases C-401/12 P to C-403/12 P, Vereniging.

48 Judgement in case C-240/09, VLK.

49 B. Iwańska, op. cit., p. 11.

50 See judgement of the SAC of 23 February 2011, II OSK 2516/10.

51 The Committee also stresses that the attribute of direct application of international agreements should not serve as an excuse for the absence of clear, transparent and consistent national regulations to implement the provisions of the Convention. See communication of the Compliance Committee of 4 June 2014 concerning Germany, ACCC/C/2008/31/DE. 
State, but also as a state whose Constitution (Article 5) refers to the principle of sustainable development. Reports on the implementation of the Convention also point to the insufficient scope of its transposition. In the opinion of the European Commission, the Polish legislation is insufficiently adapted to the Aarhus Convention. The Polish side agreed with this assessment, which means that action must be taken in this regard.

The effective protection of the rights under the Aarhus Convention is therefore one of the crucial challenges in the near future for EU courts ${ }^{52}$ as well as for the Polish legislature. Access to justice under the Aarhus Convention plays an important, if not the key, role in ensuring the effectiveness of environmental protection law, including climate protection.

\section{REFERENCES}

\section{Literature}

Baran M., Dostęp do wymiaru sprawiedliwości w obszarze ochrony środowiska w państwach członkowskich, "Europejski Przegląd Sądowy" 2020, no. 11.

Duda A., Interes prawny w polskim prawie administracyjnym, Warszawa 2008.

Filipcova B., Polskie przepisy dotyczace dostępu do wymiaru sprawiedliwości w sprawach środowiskowych - analiza istniejacych barier, "Europejski Przegląd Sądowy" 2020, no. 11.

Integracja zewnętrzna $i$ wewnętrzna nauk prawnych, eds. M. Zirk-Sadowski, B. Wojciechowski, T. Bekrycht, part 1, Łódź 2014.

Iwańska B., Zróżnicowanie i ograniczenia $w$ dostępie do wymiaru sprawiedliwości $w$ sprawach ochrony środowiska. Uwagi na tle implementacji konwencji z Aarhus w prawie unijnym, "Europejski Przegląd Sądowy" 2020, no. 10.

Iwańska B., Baran M., Access of An Environmental Organisation to Court in Light of the EU Standard Set by the Principle of Effective Legal (Judicial) Protection, "European Energy and Environmental Law Review" 2019, vol. 28(2).

Kenig-Witkowska M., Prawo ochrony środowiska Unii Europejskiej. Zagadnienia systemowe, Warszawa 2011.

Klimatyczne ABC. Interdyscyplinarne podstawy wspótczesnej wiedzy o zmianie klimatu, eds. M. Budziszewska, A. Kardaś, Z. Bohdanowicz, Warszawa 2021.

Knade-Plaskacz A., Dostęp do wymiaru sprawiedliwości w sprawach dotyczacych środowiska transpozycja trzeciego filaru Konwencji z Aarhus do prawa Unii Europejskiej, "Przegląd Prawa Ochrony Środowiska” 2014, no. 1, DOI: https://doi.org/10.12775/PPOS.2014.009.

Przybojewska I., Trzeci filar konwencji z Aarhus oraz rola Komitetu ds. Przestrzegania Konwencji z Aarhus, "Europejski Przegląd Sądowy" 2020, no. 10.

Sikora A., Constitutionalisation of Environmental Protection in EU Law, Zutphen 2020.

Wierzbowski B., Rakoczy B., Prawo ochrony środowiska. Zagadnienia podstawowe, Warszawa 2018. Wilson E., Konsiliencja. Jedność wiedzy, Poznań 2002.

52 A. Sikora, Constitutionalisation of Environmental Protection in EU Law, Zutphen 2020, pp. 202-312. 


\section{Online sources}

Handbook on European law relating to access to justice, www.echr.coe.int/Documents/Handbook_access_justice_ENG.pdf [access: 10.10.2021].

\section{Legal acts}

Act of 27 April 2001 - Environmental Protection Law (consolidated text, Journal of Laws 2020, item 1219).

Act of 21 June 2001 on the ratification of the Convention on Access to information, public participation in decision-making and access to justice in environmental matters (Journal of Laws 2001, no. 89 , item 970 ).

Act of 3 October 2008 on the dissemination of information on the environment and its protection, public participation in environmental protection and on environmental impact assessments (Journal of Laws 2013, item 1235, as amended).

Act of 9 October 2015 amending the Act on the provision of information on the environment and its protection, public participation in environmental protection and on environmental impact assessments and on certain other acts (Journal of Laws 2015, item 1936).

Constitution of the Republic of Poland of 2 April 1997 (Journal of Laws 1997, no. 78, item 483, as amended).

Convention on Access to Information, Public Participation in Decision-Making and Access to Justice in Environmental Matters, Aarhus, Denmark, 25 June 1998 (United Nations, Treaty Series, vol. 2161, p. 447).

Council Decision 2005/370/EC of 17 February 2005 on the conclusion, on behalf of the European Community, of the Convention on access to information, public participation in decision-making and access to justice in environmental matters (OJ L 124/1, 17.05.2005).

Directive 2003/4/EC of the European Parliament and of the Council of 28 January 2003 on public access to environmental information and repealing Council Directive 90/313/EEC (OJ L 41/26, 14.02.2003).

Directive 2003/35/EC of the European Parliament and of the Council of 26 May 2003 providing for public participation in respect of the drawing up of certain plans and programmes relating to the environment and amending with regard to public participation and access to justice Council Directives 85/337/EEC and 96/61/EC (OJ L 156/17, 25.06.2003).

Directive 2004/35/CE of the European Parliament and of the Council of 21 April 2004 on environmental liability with regard to the prevention and remedying of environmental damage (OJ L $143 / 56,30.04 .2004)$.

Directive 2010/75/EU of the European Parliament and of the Council of 24 November 2010 on industrial emissions (integrated pollution prevention and control) (OJ EU L 334/17, 17.12.2010).

Directive 2011/92/EU of the European Parliament and of the Council of 13 December 2011 on the assessment of the effects of certain public and private projects on the environment (OJ EU L $26 / 1,28.01 .2012$ ).

European Convention for the Protection of Human Rights and Fundamental Freedoms of 4 November 1950 (ETS no. 005, as amended).

International Covenant on Civil and Political Rights adopted by the General Assembly of the United Nations on 19 December 1966 (United Nations, Treaty Series, vol. 999, p. 171).

Regulation (EC) no. 1367/2006 of the European Parliament and of the Council of 6 September 2006 on the application of the provisions of the Aarhus Convention on Access to Information, Public Participation in Decision-making and Access to Justice in Environmental Matters to Community institutions and bodies (OJ EU L 264/13, 25.09.2006). 
Treaty of Lisbon amending the Treaty on European Union and the Treaty establishing the European Community, signed at Lisbon on 13 December 2007 (OJ C 306/1, 17.12.2007).

\section{Case law}

Application in case Duarte Agostinho and others v. Portugal and 32 other States (application no. 39371/20) - communicated on 13 November 2020 (pending).

Communication of the Compliance Committee of 24 September 2010 concerning the United Kingdom, ACCC/C/2008/33/UK.

Communication of the Compliance Committee of 4 June 2014 concerning Germany, ACCC/C/2008/31/ DE.

Decision of the SAC of 2 June 2005, II OZ 503/05.

Decision of the SAC of 7 December 2005, II OZ 1146/05.

Decision of the SAC of 2 February 2010, II OSK 40/10.

Judgement of the CJEU of 15 October 2009, C-263/08, Djurgården-Lilla, ECLI:EU:C:2009:631.

Judgement of the CJEU of 8 March 2011, C-240/09, Lesoochranárske zoskupenie VLK, ECLI:EU:C:2011:125.

Judgement of the CJEU of 12 May 2011, C-115/09, Bund für Umwelt und Naturschutz, ECLI:EU:C:2011:289.

Judgement of the SAC of 11 April 2004, OSK 1151/04.

Judgement of the SAC of 16 May 2006, II OSK 129/06.

Judgement of the SAC of 3 July 2007, II OSK 163/07.

Judgement of the SAC of 9 August 2007, II OSK 763/07.

Judgement of the SAC of 6 November 2007, II OSK 1393/07.

Judgement of the SAC of 18 December 2009, II OSK 1539/09.

Judgement of the SAC of 15 April 2010, II OSK 645/09.

Judgement of the SAC of 11 May 2010, II OSK 464/09.

Judgement of the SAC of 16 March 2010, II OSK 540/09.

Judgement of the SAC of 1 June 2010, II OSK 920/09.

Judgement of the SAC of 23 February 2011, II OSK 2516/10.

Judgement of the SAC of 21 April 2011, II OSK 2103/10.

Judgement of the SAC of 21 April 2011, II OSK 2022/10.

Judgement of the SAC of 11 May 2011, II OSK 548/11.

Judgement of the SAC of 31 August 2012, II OSK 851/11.

Judgement of the SAC of 16 January 2013, II OSK 1706/11.

Judgement of the SAC of 3 October 2013, II OSK 1282/12.

Judgement of the SAC of 13 October 2013, II OSK 1274/12.

Judgement of the SAC of 4 December 2013, II GSK 1307/12.

Judgement of the SAC of 6 December 2013, II OSK 54/12.

Judgement of the SAC of 13 March 2014, II OSK 2489/12.

Judgement of the SAC of 19 November 2014, II OSK 1071/13.

Judgement of the SAC of 12 May 2015, II OSK 2036/13.

Judgement of the SAC of 24 June 2015, II OSK 2808/13.

Judgement of the SAC of 16 July 2015, II OSK 1044/15.

Judgement of the SAC of 1 October 2015, II OSK 896/15.

Judgement of the SAC of 13 January 2016, II OSK 1131/14.

Judgement of the SAC of 3 March 2016, II OSK 1674/14.

Judgement of the SAC of 6 April 2016, II OSK 1920/14.

Judgement of the SAC of 19 May 2016, II OSK 2189/14. 
Judgement of the SAC of 20 May 2016, II OSK 2244/14.

Judgement of the SAC of 9 June 2016, II OSK 2415/14.

Judgement of the SAC of 28 July 2016, II OSK 1076/15.

Judgement of the SAC of 1 March 2017, II OSK 2859/16.

Judgement of the SAC of 22 August 2017, II OSK 2970/15.

Judgement of the SAC of 12 December 2017, II OSK 1523/16.

Judgement of the SAC of 19 January 2018, II OSK 833/16.

Judgement of the SAC of 19 January 2018, II OSK 1721/16.

Judgement of the SAC of 24 April 2018, II OSK 2743/17.

Judgement of the SAC of 28 August 2018, II OSK 2192/16.

Judgement of the SAC of 17 April 2019, II OSK 1479/17.

Judgement of the SAC of 8 May 2019, II OSK 652/19.

Judgement of the SAC of 23 July 2019, II OSK 2335/17.

Judgement of the SAC of 15 November 2019, II OSK 3276/17.

Judgement of the SAC of 3 December 2019, II OSK 3303/19.

Judgement of the SAC of 18 May 2020, II OSK 2710/19.

\section{ABSTRAKT}

Prawo klimatu stanowi bardzo dynamiczną gałąź prawa. Jest regulowane multicentrycznie, gdyż jako problem globalny potrzebuje szerszych niż państwowe rozwiązań systemowych. Ochrona klimatu może się odbywać również poprzez realizację praw człowieka, w tym prawa do sądu. Do wielopoziomowej regulacji jako lex generalis dochodzi więc regulacja lex specialis, w myśl której prawo do sądu uregulowano w ujęciu kolektywnym i powiązano stricte z prawem klimatu w art. 9 Konwencji z Aarhus. Celem teoretycznym i pośrednim artykułu jest zaakcentowanie związku prawa ochrony środowiska w ogólności, a prawa klimatu w szczególności, z prawami człowieka na przykładzie prawa do sądu. Celem bezpośrednim i praktycznym jest ukazanie w sposób przekrojowy roli Konwencji z w orzecznictwie Naczelnego Sądu Administracyjnego (NSA). Istotę problemu stanowi uznanie braku bezpośredniej skuteczności Konwencji, co osłabia wspomnianą ochronę. Artykuł ma charakter naukowo-badawczy, a analiza dotychczasowego orzecznictwa może mieć wartość poznawczą dla praktyki. Pierwsza część zawiera rys teoretycznoprawny i dotyczy zagadnień wprowadzających, ukazując połączenia praw człowieka z prawem klimatu oraz zakres obowiązywania Konwencji z Aarhus. Druga część dotyczy materiałów i metod badawczych oraz zawiera analizę przepisów art. 9 Konwencji dokonaną przy użyciu metody logiczno-językowej i celowościowej wykładni. W części trzeciej ukazano - niekiedy niebudzące kontrowersji, niekiedy dyskusyjne - rezultaty poszukiwań interpretacyjnych dokonywanych przez NSA. Orzekając w sprawach środowiskowych wynikających z polskiego prawa administracyjnego, NSA współstosuje z prawem krajowym akty normatywne należące do prawa europejskiego, w tym także Konwencję. Jednak sposób sformułowania jej przepisów wyklucza, w myśl linii orzeczniczej, możliwość ich bezpośredniego zastosowania, podnosząc tym samym ważkość działań legislacyjnych, a sądy administracyjne nie mogą zastąpić w tym zakresie ustawodawcy. W ramach konkluzji podkreślono, że implementacja Konwencji jest „zasadniczo prawidłowa”, co nie oznacza jednak implementacji w pełni realizującej Aarhus-type principles.

Słowa kluczowe: Konwencja z Aarhus; ochrona klimatu; prawo ochrony środowiska; prawo klimatu; prawa człowieka; sądy administracyjne; orzecznictwo 